\title{
The Effect of Bioaugmentation Strategy on the SBR Performance Treating Reject Water and Municipal Wastewater Under Various Temperature Conditions
}

\author{
Aleksandra Szaja', Joanna Szulżyk-Cieplak ${ }^{2 *}$ \\ 1 Lublin University of Technology, Faculty of Environmental Engineering, Nadbystrzycka 40B, \\ 20-618 Lublin, Poland, \\ 2 Lublin University of Technology, Faculty of Fundamentals of Technology, Nadbystrzycka 38, \\ 20-618 Lublin, Poland \\ *Corresponding author's e-mail: j.szulzyk-cieplak@pollub.pl
}

\begin{abstract}
In this study, the effect of bioaugmentation on the sequencing batch reactor (SBR) performance while treating municipal wastewater and reject water under various temperature conditions was examined. Two lab-scale SBRs, each with the active volume of $8 \mathrm{~L}$ were used to perform this research. For bioaugmentation, a mixture of wildliving Bacteria and Archaea in a dose $0.25 \mathrm{~mL}$ was added to SBR A, while SBR B was a control one. Both reactors were fed with a mixture of wastewater and $13 \% \mathrm{v} / \mathrm{v}$ reject water. During the experiment, 5 phases with different temperature range were distinguished, each one lasted $14 \mathrm{~d}$. The temperatures were investigated in $5^{\circ} \mathrm{C}$ increments, i.e. $20,25,30,25$ and $20^{\circ} \mathrm{C}$. The obtained results indicated that in the bioaugmented reactor (SBR A), lower concentrations of $\mathrm{NH}_{4}^{+}-\mathrm{N}$, TSS, $\mathrm{NO}_{2}^{-}-\mathrm{N}$ in effluent were observed as compared to control (SBR B). While for $\mathrm{NH}_{4}^{+}-\mathrm{N}$, regardless the temperature, the observed differences were statistically significant. Importantly, in both SBRs, the process was carried out in a stable way.
\end{abstract}

Keywords: activated sludge, Archaea, bioaugmentation reject water, temperature fluctuations

\section{INTRODUCTION}

Currently, the leading challenge for municipal wastewater treatment plants (WWTPs) staff is to ensure both a high-quality effluent wastewater and reduction of operating costs [Shahzad et al., 2015; Drewnowski et al., 2019; Masłoń et al., 2020]. In particular, large facilities must meet stringent requirements with regard to nitrogen and phosphorus for wastewater discharge to the environment [Mucha and Mikosz, 2021; JarominGleń et al., 2013;Barbusiński et al., 2020]. Therefore, advanced treatment technologies should be applied [Roots et al. 2020; Shourjehet al., 2020; Czarnota et al., 2020]. It is noteworthy that WWTPs aremodern facilities with high energy consumption, while the treatment process itself is multi-stage and complicated [Zubrowska-Sudol et al., 2018; Kudlek and Dudziak, 2018; Szeląg and Barbusinski 2020], so the additional method of monitoring and control are developed [Guz et al., 2015; Łagód et al., 2019; Byliński et al., 2019]. WWTP employees have to deal with many operational problems such as variable influent composition, illegal wastewater discharges and frequent breakdowns [Bartkiewicz et al., 2016; Jaromin-Gleń et al., 2020]. Additionally, temporary unstable conditions at each stage of treatment are common [Fernando Morgan-Sagastume and Grant Allen, 2003]. Among them, biological processes are the most sensitive to the occurring changes [Babko et al., 2016]. At many WWTPs, the biological nutrient removal (BNR) is realized through a nitrification-denitrification processes [Regmi et al., 2014.; Roots et al., 2019]. In the first step, ammonia is sequentially oxidized to nitrite and then into nitrate. Subsequentlyin denitrification process, nitrates are reduced to gaseous 
nitrogen. Processes of nitrification and denitrification involve different groups of microorganisms and require different process conditions [Majtacz et al., 2017; Mehrani et al., 2020; Al-Hazmi et al. 2021]. Their efficiency depends on many factors, including wastewater composition, the adopted technology as well as operational conditions [Metcalf and Eddy 2004; Alisawi, 2020; Majtacz et al., 2020].

The temperature is considered as a main parameter that can effect biological treatment [Metcalf and Eddy 2004]. Its fluctuation results from seasonal variations and industrial wastewater discharge. Typically, the temperature difference between inlet and outlet of WWTP is approx. 0.5 and $1{ }^{\circ} \mathrm{C}$. Thought, many facilities have to deal with permanent diurnal temperature fluctuations [Mąkinia et al., 2005]. Importantly, this parameter influences the reaction rates of most chemical and biological processes [Alisawi, 2020]. It also affects the fluid viscosity and dissolved oxygen levels as well as the settling properties of biomass. Particularly, the nitrification process is considerably susceptible toits fluctuations. Its optimal level should be varied between $28-32^{\circ} \mathrm{C}$ [Rodziewicz et al., 2019]. It should be noted that with its decline the nitrification rate significantly decreased [Henze et al., 2008]. Additionally, it is confirmed that at temperatures below $8-10^{\circ} \mathrm{C}$ an accumulation of nitrates in effluent is observed. [Young et al., 2017, Kim et al., 2008]. In contrast, the inhibition of nitrification is found above the temperature of $50^{\circ} \mathrm{C}$ [Metcalf and Eddy 2004]. Moreover, sudden fluctuations in this parameter are also unfavorable.The WWTP operation at varying temperatures is especially challenging [Alisawi, 2020].

In this context, the problem of reject waters has become a matter of a concern at many WWTPs. This side-stream is generated during the sewage sludge processing. Although its flow is relatively small and approx. $1.5-3 \%$. It can contribute about $30 \%$ of the ammonium nitrogen discharged to the main flow [Wett et al., 1998]. Moreover, it is characterized by unfavorable COD: $\mathrm{N}$ ratio for conventional nitrification/denitrifiaction and increased temperature [Noutsopoulos et al., 2018, Tae Kim, 2020]. The nitrogen removalfrom reject water can be realized thought various methods including OLAND (oxygen-limited autotrophic nitrification-denitrification), CANON (Completely Autotrophic Nitrogen Removal Over Nitrite) and ANAMMOX (anaerobic ammonium oxidation) as well as SHARON (Single reactor system for High activity Ammonium Removal Over Nitrite)ANAMMOX processes [Al-Hazmi et al., 2019; Kim I.T. et al., 2020; Shourjehi et al., 2021]. However, they require the construction of separate devices [Meyer and Wilderer, 2004]. Still, at many WWTPs, such side-streams are recycled to the bioreactors influent without separate treatment, often resulting in its temporary overloading [Podstawczyk et al., 2017]. Besides, it might contributeto increased costs of treatment related with aeration [Kwon et al., 2019; Suschka and Grubel, 2014]. On the other hand, many WWTPs cannot afford to build an additional object for the reject water treatment.

Bioaugmentation is a strategy that has been widely applied to biological reactors to support or to improve the process [Ji et al., 2020]. Therein, the selected strains or mixed cultures are added to reactors to improve the catabolism of specific compounds. It is considered a promising technique to overcome many practical difficulties in WWTPs, as well as to enhance the removal efficiency [Herrero and Stuckeya, 2015; Grabas et al., 2016]. Importantly, compared to other techniques, it allows reacting to the changes that appear periodically. Therefore, it has considerable flexibility and is associated with lower investment and operating costs related e.g. with the construction of additional advanced devices at WWTP [Montusiewicz, 2014]. It has been applied to many WWTPs when the existing facilities become insufficient to treat the increasedflow or load contained in wastewater [Ma et al., 2009]. It has proven effectiveness in supporting the activated sludge process (mainly nitrification) operated at low temperature [Plaza et al., 2001; Head and Oleszkiewicz, 2004]. Bioaugmentation has also been used to protect the structure and function of theactivated sludge microbial community against a various harmful and toxic substances e.g. xenobiotics [Boon et al., 2003] and landfill leachate [Michalska et al, 2020]. Additionally, this technique has been adopted to improve the biodegradation of recalcitrant organic pollutants presented in municipal and industrial wastewater e.g. endocrinedisrupting compounds (EDCs), pharmaceutical [Boonnorat et al., 2018, Nizla et. al, 2016], azo dye, [Kv N.S., 2021] pesticides, surfactants, and heavy metals [Almeida et al., 2017; Ji et al., 2019; Nguyen et al., 2019]. However, the utilization of bioaugmentation might be unsuccessful, it can be caused by improper selection 
of microorganisms, application of insufficient acclimatization period, inadequate inoculum size as well as substrate availability [Herrero and Stuckeya, 2015; Lebiocka et al., 2018].Therefore, there is still a need to conduct research in this area.

In this work the influence of bioaugmentation on the efficiency of reject water and municipal wastewater co-treatment under different temperature conditions was examined. For bioaugmentation, a solution of wild-living bacteria and Archaea from Yellowstone National Park (Archaea Solutions Inc.) was used.

\section{MATERIALS AND METHODS}

\section{Lab-scale Sequencing Batch Reactor (SBR)}

Experiment was conducted in two lab-scale SBRs with an active volume of $8 \mathrm{~L}$ and a diameter of $0.25 \mathrm{~m}$ (Fig. 1). To keep the operating temperature both reactors were placed in water bath. The reactors were equipped with a mechanical agitators, $\mathrm{DO}$ and $\mathrm{pH}$ probes, an air membrane diffusers, influent and effluent tanks. Moreover, the installation was monitored by control unit.

The SBRs were operated in two 12 hour cycles per day. Each one consisted of the subsequent repeated stages: supplying $(0.5 \mathrm{~h})$, reaction including mixing $(2 \mathrm{~h})$ and aeration $(7 \mathrm{~h})$, sedimentation $(1.5 \mathrm{~h})$ discharging $(0.5 \mathrm{~h})$ as well as operational phase for sampling and additional technical services.
The reactor was inoculated with a mixed liquor from WWTP in Lublin. This sample was taken from the activated sludge reactor using a modified Bardenpho method. It was characterized by the following parameters: mixed liquor suspended solids (MLSS) $3.21 \mathrm{~g} / \mathrm{L}$, mixed liquor volatile suspended solids (MLVSS) $2.45 \mathrm{~g} / \mathrm{L}$ and sludge retention time (SRT) of 14.9 days,. The sludge volume index (SVI) was $236 \mathrm{~mL} / \mathrm{g}$, while the food to microorganism ratio (F/M ratio) $-0.12 \mathrm{gBOD}_{5} / \mathrm{g}$ MLVSS $\cdot \mathrm{d}$ [Szaja and Szulżyk-Cieplak, 2020].

\section{Substrate characteristic}

The wastewater used as influent for SBRs was taken from the effluent of primary sedimentation tank. In turn, the reject water used in the experiment was originated from dewatering belt press. At Lublin WWTP, the sewage sludge were treated involving the following devices: gravityand mechanical thickeners, anaerobic digesters (mesophilic conditions), belt pressesand a thermal drying unit.

The samples of wastewater and reject water were collected twice a week. Then these were immediately delivered to the laboratory, where they were kept at $4^{\circ} \mathrm{C}$ in a refrigerator. Before feeding the reactors, the samples were adjusted to reach the determined temperature; then, they were mixed in the assumed proportions by a lowspeed agitator. The characteristic of both samples is presented in Table 1.

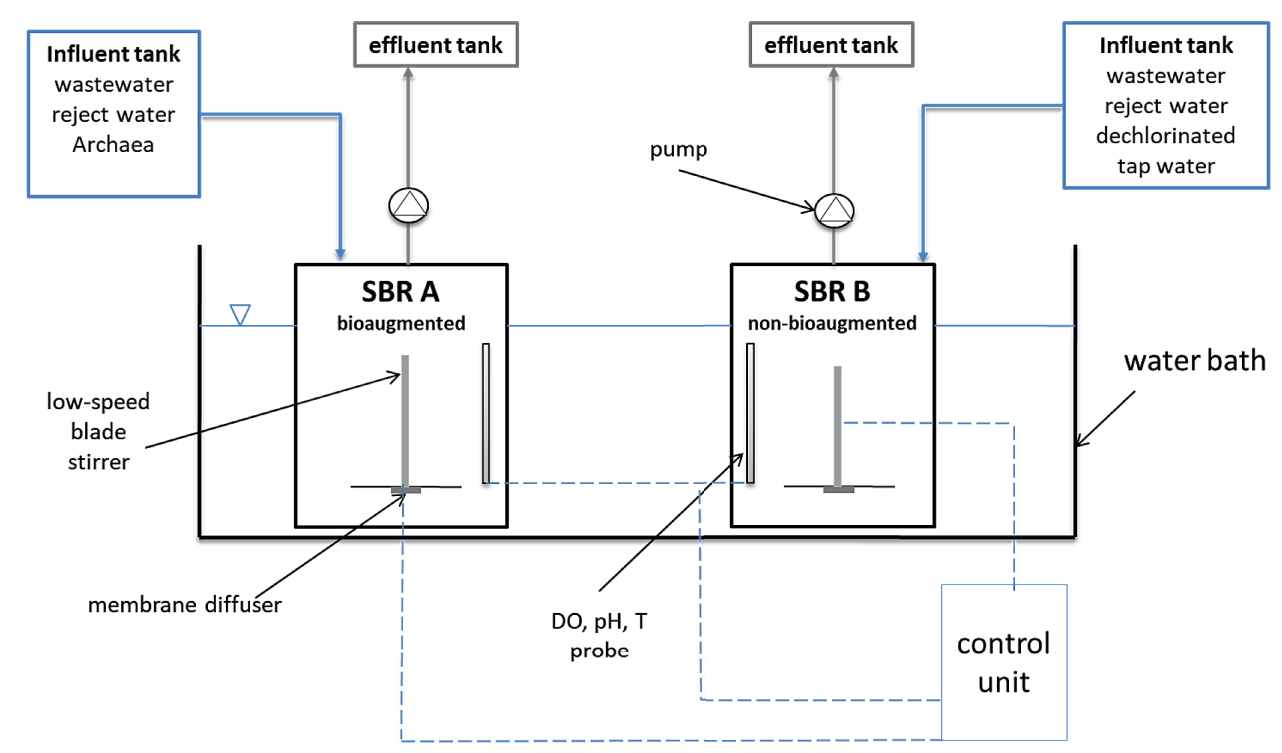

Figure 1. The laboratory SBRs utilized in the present study 
Table 1. The characteristic of wastewater and reject water utilized in the present study (average values and standard deviation are given)

\begin{tabular}{|l|c|c|}
\hline \multicolumn{1}{|c|}{ Parameter } & Reject water & Wastewater \\
\hline $\mathrm{COD}[\mathrm{mg} / \mathrm{L}]$ & $167.3 \pm 7,4$ & $663 \pm 5.1$ \\
\hline $\mathrm{NO}_{3}{ }^{-}-\mathrm{N}[\mathrm{mg} / \mathrm{L}]$ & $0.83 \pm 0,22$ & $0.95 \pm 0.2$ \\
\hline $\mathrm{NO}_{2}{ }^{-}-\mathrm{N}[\mathrm{mg} / \mathrm{L}]$ & $0.21 \pm 0,11$ & $0.24 \pm 0.05$ \\
\hline $\mathrm{NH}_{4}{ }^{+}-\mathrm{N}[\mathrm{mg} / \mathrm{L}]$ & $365.5 \pm 25,5$ & $6.5 \pm 0.01$ \\
\hline $\mathrm{TP}[\mathrm{mg} / \mathrm{L}]$ & $17.6 \pm 2.5$ & $8.5 \pm 0.2$ \\
\hline $\mathrm{pH}$ & $7.8 \div 8,06$ & $7.58 \div 8.01$ \\
\hline TSS [mg/L] & $21.33 \pm 2.1$ & $285.7 \pm 1.61$ \\
\hline Turbidity [NTU] & $15.81 \pm 3.9$ & $134.7 \pm 1, .55$ \\
\hline
\end{tabular}

For bioaugmentation, the wild-living bacteria and Archaea from Yellowstone National Park, USA were applied (Archea Solutions Inc.). To SBRs it was added as a solution made of a solid substrate. Its production was realized in a specially constructed preparation unit operating in a continuous mode. The procedure of the mixture preparation was presented in the study performed by Lebiocka et al., 2018. Its composition was as follows: COD $-22.0 \pm 1.0 \mathrm{mg} / \mathrm{L}$, TSS $-6.0 \pm 1.0 \mathrm{mg} / \mathrm{L}, \mathrm{TN}-75 \pm 1.0 \mathrm{mg} / \mathrm{L}, \mathrm{N}-\mathrm{NH} 4-$ $0.4 \pm 0.02 \mathrm{mg} / \mathrm{L}, \mathrm{TP}-0.17 \pm 0.03 \mathrm{mg} / \mathrm{L}, \mathrm{pH} 7.16$ [Szaja et al., 2018].

\section{Experimental set-up}

The start-up period for biomass adaptationlasted 2 weeks. After this time, the SBR A was supplied by the bioaugmentation product in amount of $0.25 \mathrm{~L}$. The second reactor - SBR B was the control one.. In this case, the bioaugmentation product was replaced by an analogous amount of distilled water to kept constant retention time. The acclimatization of biomass to the bioaugmentation product was achieved after 3 weeks. During this period, a constant temperature of $20 \pm 0.5^{\circ} \mathrm{C}$ was maintained in both SBRs. Subsequently, both reactors were fed with a mixture of wastewater and $13 \% \mathrm{v} / \mathrm{v}$ reject water (Table 2 ).

During the experiment, 5 phases with different temperature range were distinguished, each one lasted $14 \mathrm{~d}$. The consecutive temperatures

Table 2. The characteristics of feedstock composition

\begin{tabular}{|c|c|c|}
\hline Reactor & SBR A & SBR B \\
\hline \multirow{3}{*}{$\begin{array}{c}\text { Feedstock } \\
\text { composition }\end{array}$} & wastewater $2.5 \mathrm{~L}$ & wastewater $2.5 \mathrm{~L}$ \\
\cline { 2 - 3 } & reject water $0.4 \mathrm{~L}$ & reject water $0.4 \mathrm{~L}$ \\
\cline { 2 - 3 } & $\begin{array}{c}\text { bioaugmentation } \\
\text { product } 0.25 \mathrm{~L}\end{array}$ & $\begin{array}{c}\text { Dechlorinated tap } \\
\text { water } 0.25 \mathrm{~L}\end{array}$ \\
\hline
\end{tabular}

were investigated $20,25,30,25$ and $20^{\circ} \mathrm{C}$. In this work, the effect of both the increase and decrease of this parameter was examined.

\section{Analytical methods}

The composition of wastewater and reject water was determined after their delivery to the laboratory. While the characteristic of seed sludge and bioaugmentation product was analyzed once. The following parameters were controlled: the total chemical oxygen demand (COD), total nitrogen $(\mathrm{TN})$, ammonia nitrogen $\left(\mathrm{NH}_{4}^{+}-\mathrm{N}\right)$, nitrate nitrogen $\left(\mathrm{NO}_{3}^{-}-\mathrm{N}\right)$ and nitrite nitrogen $\left(\mathrm{NO}_{2}^{-}\right.$ $\mathrm{N})$. These were made using Hach Lange UV-VIS DR 5000 (standard test cuvettes). The $\mathrm{pH}$ and DO values were monitored by a HQ 40D HachLange multimeter (Hach, Loveland, CO, USA). Moreover, turbidity, TSS (total suspended solid) and VSS (volatile suspended solid) were monitored. Total and volatile suspended solids were measured on the basic of the Standard Methods for the Examination of Water and Wastewater (APHA, 2005). The average values are presented, while the differences were assumed to be statistically significant at $\mathrm{p}<0.05$.

\section{RESULTS AND DISCUSSION}

The composition of reject water mainly depends on the stage of sludge treatment. However, the type of applied devices and the adopted process conditionsare also significant. The highest concentrations of ammonium nitrogen, total phosphorus and nitrogen as well as alkalinity are found in the samples originated after anaerobic digestion process. These wastewaters are characterized by higher $\mathrm{pH}$ level and increased temperature. It is noteworthy that its flow is lower than these generated in sludge thickening processes. The reject water from primary and waste thickening units contains a significant share a non-biodegradable organic matter fraction and increased solids content [van Loosdrechtand Salem, 2006; Noutsopoulos et al., 2018; Mucha and Mikosz, 2021]. As it was mentioned above, the reject water that supplied the SBR was collected from dewatering belt press (Table 1). As compared to the results presented in different studies, it indicates an increased content of $\mathrm{NH}_{4}^{+}-\mathrm{N}$, while COD, TP as well as TSS were reduced [Noutsopoulos et al., 2018; Mucha and Mikosz, 2021]. 
The observed differences might have resulted from variable sewage sludge composition and adopted process conditions (Table 1). Moreover, the reject water share in the influent was considerable and it reached $13 \% \mathrm{v} / \mathrm{v}$. Therefore, its contribution to SBR without pre-treatment might cause a process instability and deterioration of treatment efficiency[Kim et al., 2020].

Figures 2 and 3 present the average composition of effluents from the laboratory reactors.

In the first phase of experiment, the temperature of $20^{\circ} \mathrm{C}$ was maintained. Therein, the average concentration of $\mathrm{NO}_{3}^{-}-\mathrm{N}$ in the effluent of bioaugmented reactor was higher as compared to control one (Fig. 2a). However, the observed the differences were not statistically significant.. In SBR A, it reached $18.04 \pm 1.99 \mathrm{mg} / \mathrm{L}$, while in SBR B it was $16.06 \pm 0.59 \mathrm{mg} / \mathrm{L}$. Additionally, in this case greater variations in obtained results were observed in the bioaugmented reactor.

A different tendency was found with regard to $\mathrm{NO}_{2}^{-}-\mathrm{N}^{-}$and $\mathrm{NH}_{4}^{+}-\mathrm{N}$ (Fig. 2 b, c). Importantly, significantly lower concentrations were observed in the bioaugmented reactor. For ammonia nitrogen the average value was $2.2 \pm 0.68 \mathrm{mg} / \mathrm{L}$ in SBR A, while in control (SBR B) it was $5.46 \pm 0.87 \mathrm{mg} / \mathrm{L}$. With regard to $\mathrm{NO}_{2}^{-}-\mathrm{N}$, the average concentrations were $0.29 \pm 0.04$ and $0.37 \pm 0.04 \mathrm{mg} / \mathrm{L}$

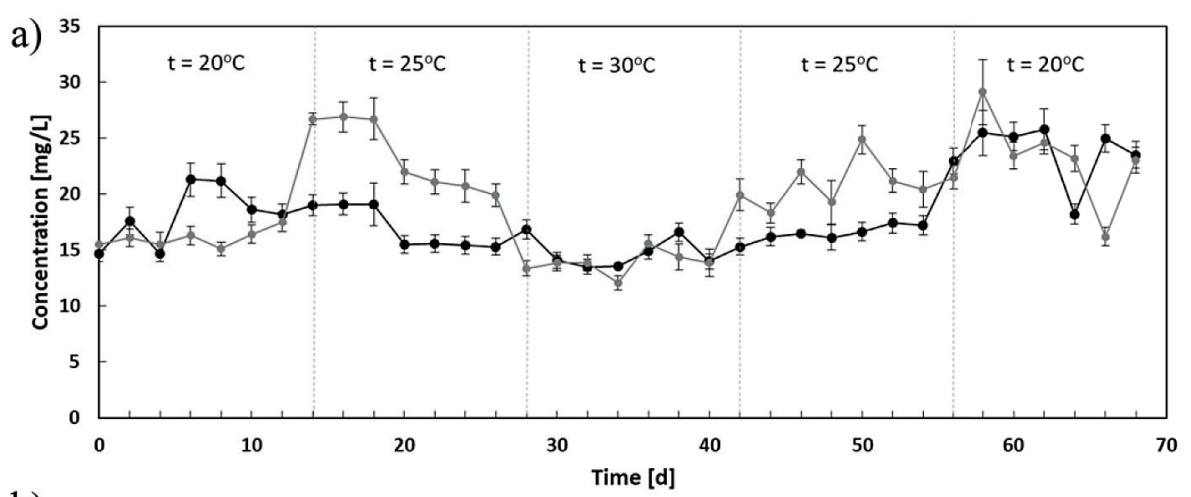

b)

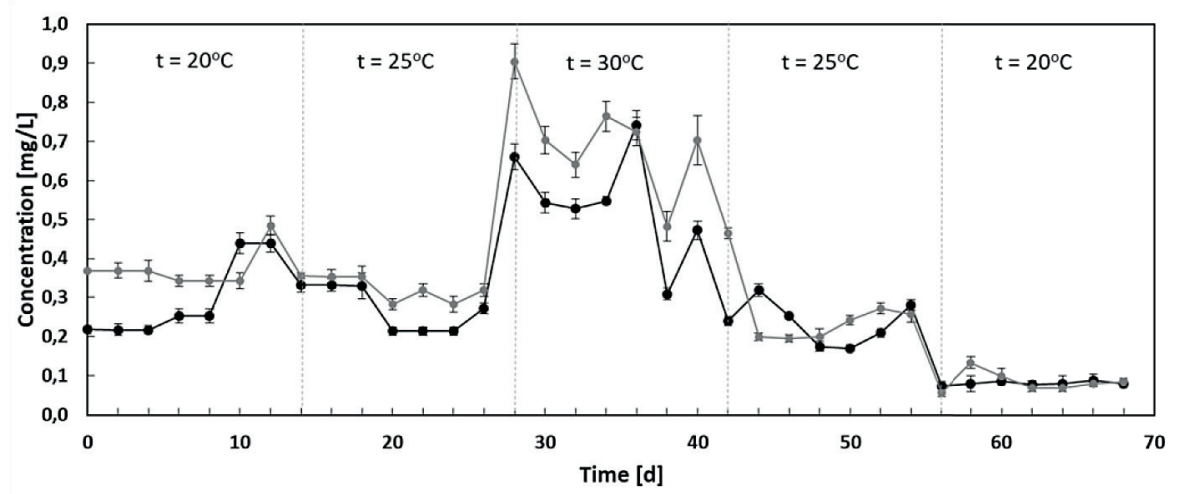

c)

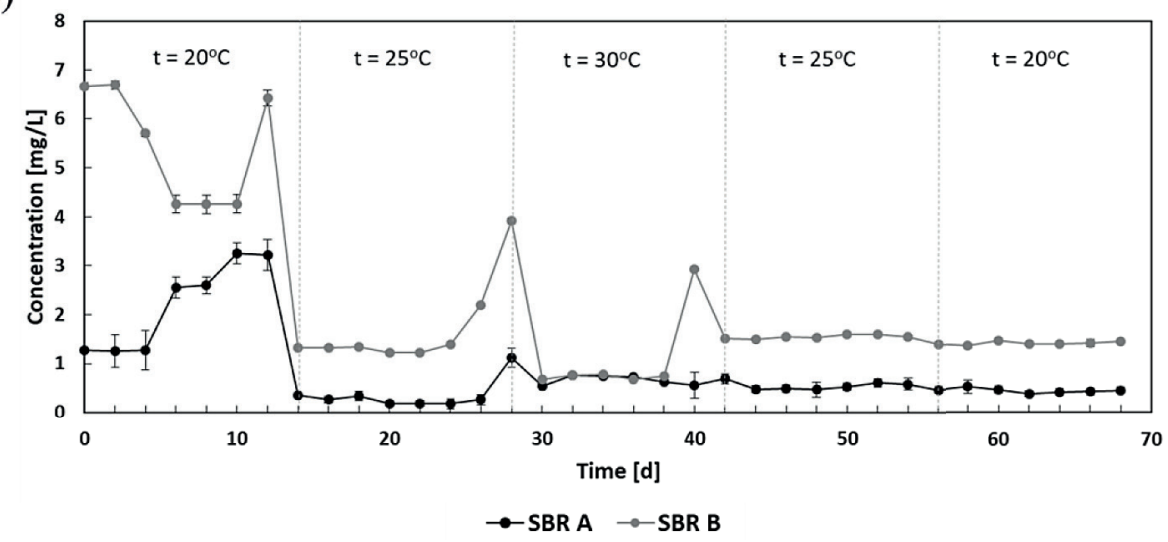

Figure 2. The average concentrations of a) nitrate nitrogen $b$ ) nitrite nitrogen c) ammonia nitrogen in the effluent of bioaugmented reactor (SBR A) and non- bioaugmented reactor (SBR B) (average data and standard deviations are presented) 
a)

b)
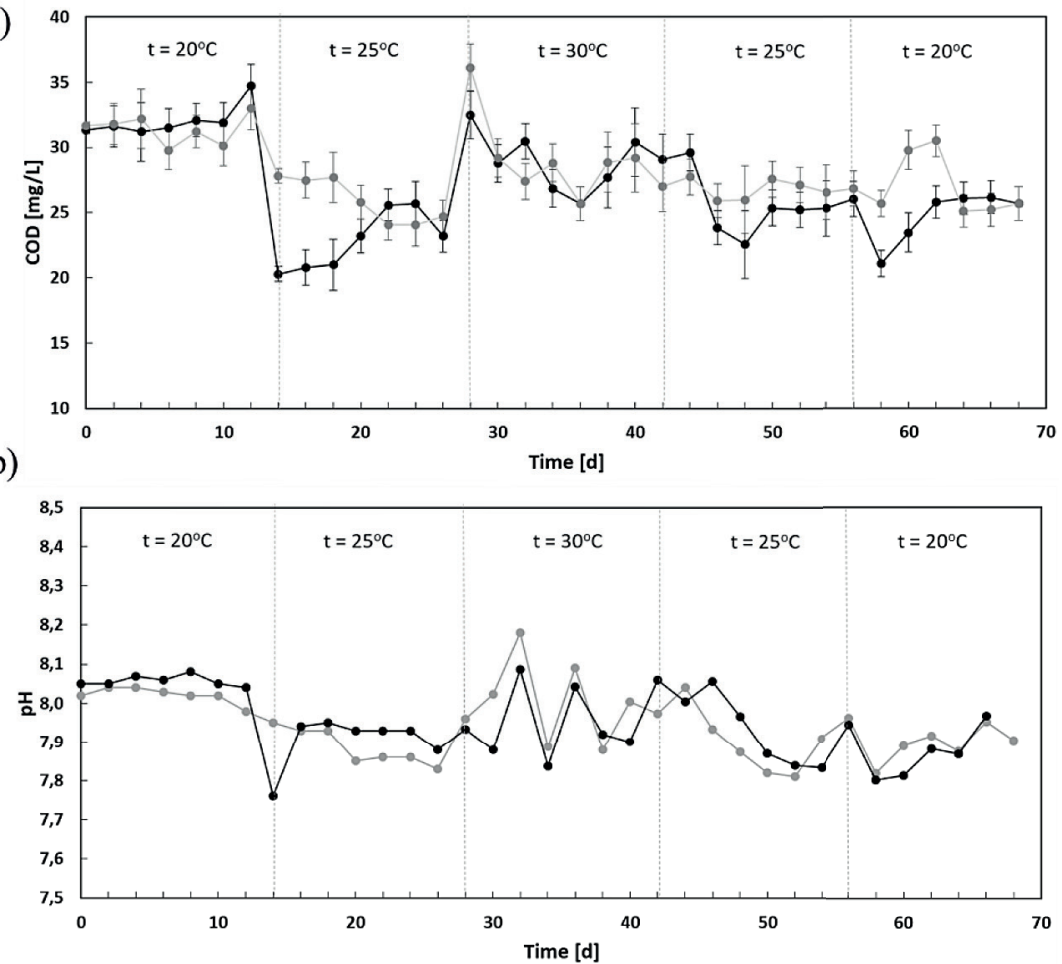

c)

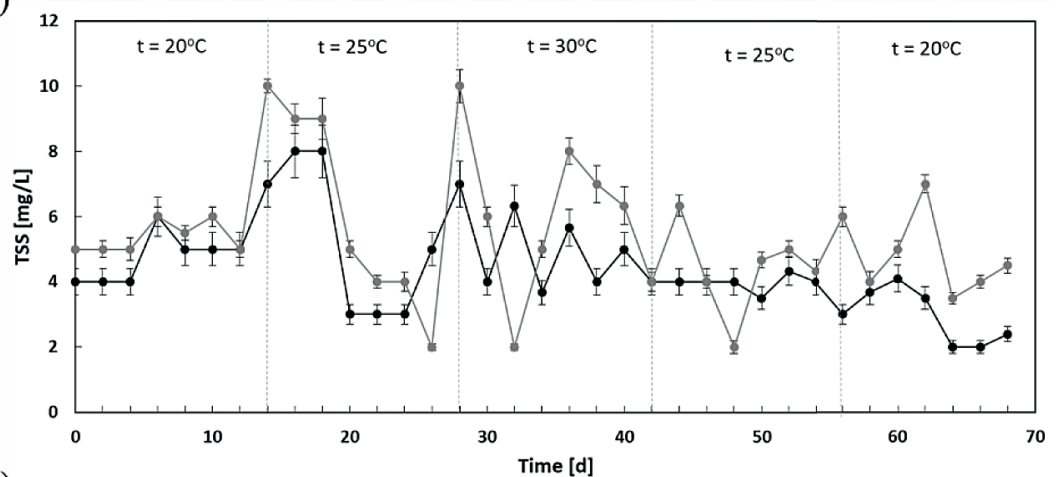

d)

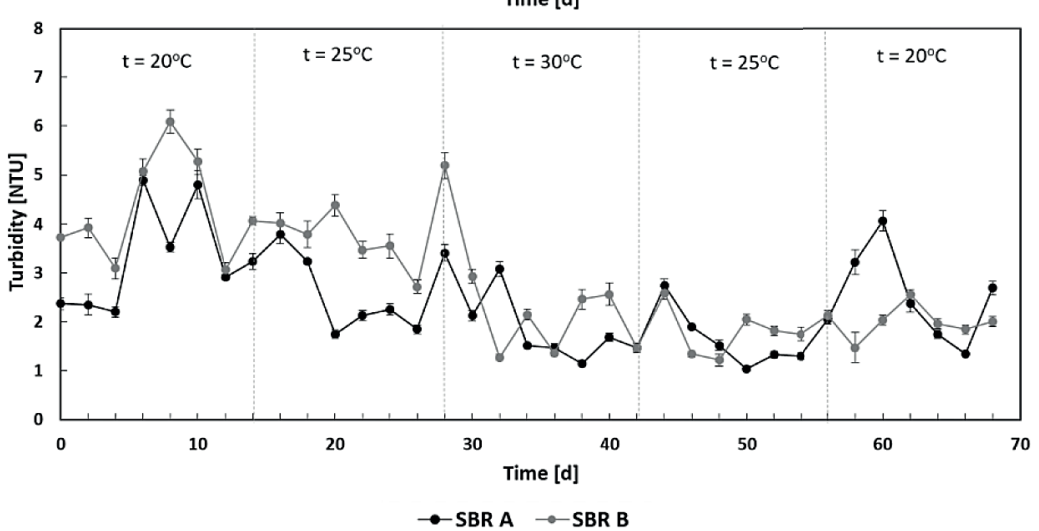

Figure 3. The composition of effluent in bioaugmented and non- bioaugmented SBR a) COD concentration and b) $\mathrm{pH}$ value c) TSS concentration and d) turbidity value (average data and standard deviations are presented)

in bioaugmented and non-bioaugmented SBR, respectively.

However, major removal efficiencies of $\mathrm{NH}_{4}^{+}-\mathrm{N}$ were achievedin both SBRs. In SBR A it was $96 \%$, while in SBR B it was accounted of $86 \%$. It should be noticed that in both reactors, at the beginning of the experiment, significant daily fluctuations in the $\mathrm{NH}_{4}^{+}-\mathrm{N}$ contents were found. However, in the case of bioaugmented SBR, this observation was noticed after $6^{\text {th }}$ day of operation. It might be related with a change of the wastewater composition that supplied reactors that was 
enriched with $13 \% \mathrm{v} / \mathrm{v}$ of reject water. In the startup period, the SBRs were only fed by the wastewater taken from the effluent of primary sedimentation tank. The microorganisms needed an additional time for acclimatization to enhanced $\mathrm{NH}_{4}^{+}-\mathrm{N}$ content discharged to influent. Importantly, in the bioaugmented SBR, the growth of this parameter was observed with a delay. This fact might indicate a protective effect of microorganisms from the Archaea domain on the activated sludge process. It has been confirmed that Archaeaplay a critical role in nitrification [You et al., 2009]. They showed a considerable resistance under extreme environmental conditions e.g. low/high temperature and low oxygen level [Yin et al., 2018]. They occurred in various environments such as deep ocean,thermal springs, marine and fresh waters, soils and wastewater treatment systems [Liu et al., 2017]. The adaptation ability of Archaea to temperature changes is related with the special structure of glycerol ether in the cell membrane [Yin et al., 2018]. At the existing WWTPs, this effect might allow the operator to quickly counteract or limit the negative effects related e.g. to supply of highly concentrated wastewater or illegal discharges.

As is shown in figure $3 \mathrm{a}$, at $20^{\circ} \mathrm{C}$ the COD concentrations in bioaugmented and non-bioaugmented reactor were comparable, in both SBRs the average value was approx. $32 \mathrm{mg} / \mathrm{L}$.

Additionally, in the bioaugmented reactor the lower values of TSS and turbidity were found; however, the observed differences were no of statistical significance (Fig. 3 c, d). The average TSS content reached 4.5 and $5.36 \mathrm{mg} / \mathrm{L}$ in bioaugmented and non- bioaugmented SBR, respectively. In turn, the averages values of turbidity were $3.3 \pm 0.85$ and $4.32 \pm 0.87 \mathrm{NTU}$ in SBR A and SBR B, respectively. A significantly increased $\mathrm{pH} 8.06 \pm 0.01$ was noticed in SBR A. In turn, in non-bioaugmented reactor it was $\mathrm{pH} 8.02 \pm 0.01$ (Fig. 3 b).

In the following phase, the temperature was increased to a level of $25^{\circ} \mathrm{C}$. This change resulted in a reduction of $\mathrm{NH}_{4}^{+}-\mathrm{N}$ concentration in the effluent for both SBRsas compared tothe previous stage. However, as previously, in bioaugmented SBR A, statistically lower results were obtained. The average concentrations were $0.25 \pm 0.06$ and $1.43 \pm 0.25 \mathrm{mg} / \mathrm{L}$ in bioaugmented reactor and control, respectively. As before, notable removal efficiencies were achieved, in SBR A it was $98 \%$, while in SBR B $-95 \%$. In this stage, after $14 \mathrm{~d}$ of operation, -a stabilized concentrations in the effluent of both SBRs were obtained. In the case of $\mathrm{NO}_{2}^{-}-\mathrm{N}$ comparable results were found in both SBRs. The average content was $0.27 \pm 0.04$ and $0.32 \pm 0.02 \mathrm{mg} / \mathrm{L}$ in SBR A and control SBR, respectively. Regarding $\mathrm{NO}_{3}^{-}-\mathrm{N}$, significantly increased concentrations were found in the non-bioaugmented reactor. Therein, this parameter was established on the level of $23.4 \pm$ $2.36 \mathrm{mg} / \mathrm{L}$. While, in the bioaugmented SBR A it was $17.0 \pm 1.43 \mathrm{mg} / \mathrm{L}$.

It is noteworthy that the average concentration of COD was significantly lower in SBA A, it reached $22.8 \pm 1.4 \mathrm{mg} / \mathrm{L}$. In turn, in SBR B it was $25.9 \pm 1.26 \mathrm{mg} / \mathrm{L}$. However, only up to $6 \mathrm{~d}$ more favorable results were obtained in the bioaugmented reactor. Compared to the previous phase, lower $\mathrm{pH}$ values were obtained for SBR A and SBR B. For both, similar results were obtained, amounting to $\mathrm{pH}$ 7.9.

The highest daily variability was shown in the case of TSS. Moreover, the observed differences between reactors were not statistically significant. The average values were $5.29 \pm 1.75$ and $6.14 \pm 2.3 \mathrm{mg} / \mathrm{L}$ in SBR A and SBR B, respectively. Regarding turbidity, in bioaugmented reactor, a significantly lower value of $2.61 \pm 0.59 \mathrm{NTU}$ was found. In the non-bioaugmented one, it was $3.71 \pm 0.4$ NTU.

In the $3 \mathrm{rd}$ stage, the temperature was increased by further $5^{\circ} \mathrm{C}$. At $30^{\circ} \mathrm{C}$, greater concentrations of $\mathrm{NO}_{2}^{-}-\mathrm{N}, \mathrm{NH}_{4}^{+}-\mathrm{N}$ and $\mathrm{COD}$ were observed than in the previous phase. Despite this fact, it should be noticed that the effluent concentrations in the bioaugmented reactor were lower than in the nonbioaugmented one. This might also indicate a beneficial effect of Archaea on the reactor performance under increased temperature.

The average values of $\mathrm{NH}_{4}{ }^{+}-\mathrm{N}$ were $0.73 \pm 0.15$ and $1.5 \pm 1.0 \mathrm{mg} / \mathrm{L}$ in SBR A and control SBR, respectively. It is noteworthy that a notable removal efficiency compared to previous phases was still achieved. In SBR A it was $96 \%$, while in SBR B $-89 \%$.

Regarding COD, comparable results were achieved in the bioaugmented and non-bioaugmented reactors. In both SBRs, it was approx. $29 \mathrm{mg} / \mathrm{L}$. However, increased concentrations were obtained in comparison to the previous phase. A similar tendency wasfound for $\mathrm{NO}_{3}^{-}-\mathrm{N}$. In this case, in both SBRs the average concentration was approx. $14 \mathrm{mg} / \mathrm{L}$. However, the obtained results were lower than in the previous stages. 
Importantly, the rise of temperature to $30^{\circ}$ Ccaused agrowth in the $\mathrm{NO}_{2}^{-}-\mathrm{N}$ content. In this phase, the highest values were achieved thought the experiment. The obtained results were $0.54 \pm 0.1$ and $0.7 \pm 0.09 \mathrm{mg} / \mathrm{L}$. During this phase, the $\mathrm{pH}$ and TSS values varied significantly. Nevertheless, considering the mean values, comparable results were obtained in both SBRs. It was $\mathrm{pH} 7.94 \pm 0.07$ and $\mathrm{pH} 8.0 \pm 0.08$ in the bioaugmented and non-bioaugmented reactor, respectively. In turn, TSS was $5.1 \pm 0.95$ and $6.33 \pm 1.85 \mathrm{mg} / \mathrm{L}$ in the bioaugmented SBR and control SBR, respectively. Regarding turbidity, similar results in both SBRs were obtained. This parameter reached approx. 2.5 NTU.

In the following phase, the temperature was reduced to $25^{\circ} \mathrm{C}$. In this stage, the $\mathrm{NO}_{2}^{-}-\mathrm{N}$ concentrations returned to the level noted for 20 and $25^{\circ} \mathrm{C}$. The similar average value of $0.25 \mathrm{mg} / \mathrm{L}$ was found in both SBRs. Regarding the $\mathrm{NH}_{4}^{+}-\mathrm{N}$ content, comparable results to theprevious phase were found in the bioaugmented reactor with the average concentration of $0.55 \pm 0.06 \mathrm{mg} / \mathrm{L}$. However, in the case of the non-bioaugmented one, statistically higher values were observed. In SBR B, the change in temperature contributed to an increase in this parameter as compared to the previous stage. The average concentration was $1.54 \pm 0.03 \mathrm{mg} / \mathrm{L}$. In relation to temperature of $30^{\circ} \mathrm{C}$, a growth in $\mathrm{NO}_{3}{ }^{-}-\mathrm{N}$ content was noted, greater for the non-bioaugmented SBR. The average values were $16.48 \pm 0.53$ and $20.85 \pm 1.59 \mathrm{mg} / \mathrm{L}$ in bioaugmented SBR and control one, respectively.

Considering COD, a reduction of this parameter was found in comparison to the prior temperature conditions. In SBR A and B, comparable average concentrations were achieved. In the bioaugmented reactor, this parameter was at the level of $25.9 \pm 1.92 \mathrm{mg} / \mathrm{L}$, while in the nonbioaugmented one it was $26.9 \pm 0.53 \mathrm{mg} / \mathrm{L}$. Similarly, there were no significant differences in $\mathrm{pH}$ between reactors. In both SBRs, it was approx. $\mathrm{pH}$ 7.95. An analogous tendency was observed with regard to turbidity. Therein, the average values were $1.62 \pm 0.42$ and $1.75 \pm 0.35 \mathrm{mg} / \mathrm{L}$ in $\mathrm{SBR}$ $\mathrm{A}$ and SBR B, respectively. Moreover, at $25^{\circ} \mathrm{C}$ lower values were found, as compared to $30^{\circ} \mathrm{C}$. In turn, average TSS reached a level of $4.0 \pm 0.18$ and $4.3 \pm 0.97 \mathrm{mg} / \mathrm{L}$ in SBR A and SBR B, respectively. However, in the case of non-bioaugmented reactor, a greater daily variation of results was observed.
In the last phase, the temperature returned to the initial conditions. As compared to the previous stage, the $\mathrm{NH}_{4}^{+-} \mathrm{N}$ content has not changed significantly, similar values were observed. In SBR A, it was $0.44 \pm 0.03$, while in SBR B $1.41 \pm 0.03 \mathrm{mg} / \mathrm{L}$. A similar tendency was found also for COD. Therein, the average concentrations were $24.9 \pm 1.43$ and $26.9 \pm 1.67 \mathrm{mg} / \mathrm{L}$ in the bioaugmented and control SBR, respectively. Regarding $\mathrm{NO}_{2}^{-}-\mathrm{N}$, the lowest concentrations in the experiment were observed. The mean valueof $0.09 \mathrm{mg} / \mathrm{L}$ in both SBRs was obtained. In the case of $\mathrm{NO}_{3}^{-}-\mathrm{N}$ the increased concentrations in comparison to the previous phases were achieved. In both SBRs, the average content of this parameter was approx. $23 \mathrm{mg} / \mathrm{L}$. Additionally, at temperature of $20^{\circ} \mathrm{Cthe} \mathrm{pH}$ did not differ in both reactors, with the average value of $\mathrm{pH}$ 7.9. Turbidity in SBR A was increased, as compared to SBR B. However, the observed differences were of no statistical significance. This parameter reached a level of $2.5 \pm 0.69$ and $2.0 \pm 0.24 \mathrm{NTU}$ in the bioaugmented and control SBR B, respectively.

The greatest fluctuations in this phase were noticed for TSS. The average concentration of $2.95 \pm 0.62$ and $4.86 \pm 0.93$ was found in SBR A and SBR B, respectively.

The obtained results indicated that both reactors showed significant removal efficiencies of all analyzed parameters, especially at a temperature of 20 and $25^{\circ} \mathrm{C}$. It is noteworthy that more favorable results were found in the bioaugmented system. This might be related with an increased oxygen utilization rate, as well as its beneficial effect on microbial metabolism in activated sludge system [You et al., 2009; Gray et al., 2002; Lens at al., 1995].

Compared to other studies in the present research, significant removal efficiencies were achieved. However, in many of them reject water constituted the main substrate. In the study conducted by $\mathrm{Kim}$ et al. (2020), $\mathrm{NH}_{4}^{+}-\mathrm{N}$ was reduced to $59 \%$, while the highest concentration of $877.3 \mathrm{mg} / \mathrm{L}$ was foundin the reactor influent as compared to the presented results. In fluidizedbed reactor inoculated with Anammox sludge, the ammonium removal efficiency reached a significant value of $82 \%$ [Strous et al., 1997]. Favorable results are also obtained with the use of adsorption/ion exchange processes involving zeolites [Sperczyńska, 2016]. Therein, this parameter varied between $80-90 \%$. 
However, the implementation of bioagmentation with Archaea to an existing SBR might constitute a cost effective solution for reject water co-treatment. Compared to the methods described above, it does not require the construction of additional objects. Moreover, this strategy might support the SBR performance under the influence of various negative factors such as temperature fluctuation.

\section{CONCLUSIONS}

In the bioaugmented reactor (SBR A) lower concentrations of $\mathrm{NH}_{4}^{+}-\mathrm{N}, \mathrm{TSS}, \mathrm{NO}_{2}^{-}-\mathrm{N}$ in effluent were found, in relation to the non-bioaugmented - SBR B. Importantly, in the case of the $\mathrm{NH}_{4}^{+}-\mathrm{N}$ content, the observed differences were statistically significant. In turn, the concentrations of COD and $\mathrm{NO}_{3}^{-}-\mathrm{N}$ as well as turbidity and $\mathrm{pH}$ reached comparable levels. The greatest variations in the obtained results were found in the case of TSS in both SBRs. However, also in this case the lowest results were found in the bioaugmented reactor. The exception was the last phase with temperature of $20^{\circ} \mathrm{C}$. Importantly, in both SBRs, the process was carried out in a stable way. The obtained results indicate the possibility of using this strategy in the reactors exposed to unfavorable conditions, e.g. variable temperature.

\section{REFERENCES}

1. Al-Hazmi H., Grubba D., Majtacz J. and Kowal P. 2019. Process Performance and Microorganisms Community Composition under Different $\mathrm{C} / \mathrm{N}$ Ratio. Water, 11, 1-17.

2. Al-Hazmi H., Xi L., Majtacz J., Kowal P., Xie L. and Mąkinia J. 2021. Optimization of the Aeration Strategies in a Deammonification Sequencing Batch Reactor for Efficient Nitrogen Removal and Mitigation of N2O Production. Environ. Sci. Technol., 55, 1218-1230.

3. AlisawiH.A.O. 2020. Performance of wastewater treatment during variable temperature. Appl. Water Sci., 10, 1-6.

4. Almeida C.M.R., Oliveira T., Reis I., Gomes C.R. and Mucha A.P. 2017. Bacterial community dynamic associated with autochthonous bioaugmentation for enhanced $\mathrm{Cu}$ phytoremediation of salt-marsh sediments. Mar. Environ. Res., 132, 68-78.

5. Babko R., Jaromin-Gleń K., Łagód G., Pawłowska M. and Pawłowski A. 2016. Effect of drilling mud addition on activated sludge and processes in sequencing batch reactors. Desalin. Water Treat., 57, 1490-1498.

6. Barbusiński K., Szeląg B. and Studziński J. 2020. Simulation of the influence of wastewater quality indicators and operating parameters of a bioreactor on the variability of nitrogen in outflow and bulking of sludge: Data mining approach. Desalin. Water Treat., 186, 134-143.

7. Bartkiewicz L., Szeląg B. and Studziński, J. 2016. Impact assessment of input variables and ANN model structure on forecasting wastewater inflow into sewage treatment plants, OchronaŚrodowiska, 38, 2, 29-36. (in Polish)

8. Boon N., Top E.M., Verstraete W. and Siciliano S.D. 2003. Bioaugmentation as a tool to protect the structure and function of an activated-sludge microbial community against a 3-chloroaniline shock load. Appl. Environ. Microbiol., 69, 1511-1520.

9. Boonnorat J., Techkarnjanaruk S., Honda R., Angthong S., Boonapatcharoen N., Muenmee S. andPrachanurak, P. 2018. Use of aged sludge bioaugmentation in two-stage activated sludge system to enhance the biodegradation of toxic organic compounds in high strength wastewater. Chemosphere, 202, 208-217.

10. Byliński H., Sobecki A. and Gebicki J. 2019. The use of artificial neural networks and decision trees to predict the degree of odor nuisance of post-digestion sludge in the sewage treatment plant process. Sustain., 11, 4407.

11. Czarnota J., Tomaszek J.A., Masłoń A., Piech A. and Lagód G. Powdered Ceramsite and Powdered Limestone Use in Aerobic Granular Sludge Technology. Materials, 13, 3894.

12. Drewnowski J., Remiszewska-Skwarek A., Duda S. and Łagód G. 2019. Aeration process in bioreactors as the main energy consumer in a wastewater treatment plant. Review of solutions and methods of process optimization. Processes, 7, 311.

13. Grabas M., Tomaszek J., Czerwieniec E., Masłoń A. and Łuczyszyn, J. 2016. Application of a biopreparation with cultures of effective microorganisms to the processing of wastewater sludge on a semiindustrial scale. Environ. Prot. Eng., 42, 33-44.

14. Gray N.D., Miskin I.P., Kornilova, O., Curtis T.P. and Head I.M. 2002. Occurrence and activity of archaea in aerated activated sludge wastewater treatment plants. Environ. Microbiol., 4, 158-168.

15. Guz Ł., Łagód G., Jaromin-Gleń K., Suchorab Z., Sobczuk H. and Bieganowski A. 2015. Application of gas sensor arrays in assessment of wastewater purification effects. Sensors, 15, 1-21.

16. Head M.A. and Oleszkiewicz J.A. 2004. Bioaugmentation for nitrification at cold temperatures. Water Res., 38 (3), 523-530.

17. Henze M., Van Loosdrecht M.C.M., Ekama G. andBrdjanovic D. 2008. Biological wastewater treatment: principles, modelling and design, IWA 
Publishing, London.

18. Herrero M. and Stuckey D.C. 2015.Bioaugmentation and its application in wastewater treatment: A review. Chemosphere, 140, 119-128.

19. Jaromin-Glen K., Babko R., Kuzmina T., Danko Y., Łagód G., Polakowski C., Szulżyk-Cieplak J. and Bieganowski A. 2020. Contribution of prokaryotes and eukaryotes to $\mathrm{CO} 2$ emissions in the wastewater treatment process. PeerJ, 2020, 1-14.

20. Jaromin-Glen K., Babko R., Lagód G. and Sobczuk H. 2013. Community composition and abundance of protozoa under different concentration of nitrogen compounds at "Hajdów" wastewater treatment plant. Ecol. Chem. Eng. S, 20, 127-139.

21. Ji J., Kakade A., Zhang R., Zhao S., Khan A., Liu P. and Li X. 2019. Alcohol ethoxylate degradation of activated sludge is enhanced by bioaugmentation with Pseudomonas sp. LZ-B. Ecotoxicol. Environ. Saf., 169, 335-343.

22. Ji J., Kulshreshtha S., Kakade A., Majeed S., Li X. and Liu P. 2020.Bioaugmentation of membrane bioreactor with Aeromonashydrophila LZ-MG14 for enhanced malachite green and hexavalent chromium removal in textile wastewater. Int. Biodeterior. Biodegrad., 150, 104939.

23. Kim I.T., Lee Y.E., Jeong Y. and Yoo Y.S. 2020. A novel method to remove nitrogen from reject water in wastewater treatment plants using a methane- and methanol-dependent bacterial consortium. Water Res., 172, 115512.

24. Kim J.H., Guo X. and Park H.S. 2008. Comparison study of the effects of temperature and free ammonia concentration on nitrification and nitrite accumulation. Process Biochem., 43, 154-160.

25. Kudlek E. and Dudziak M. 2018. The assessment of changes in the membrane surface during the filtration of wastewater treatment plant effluent. Desalin. Water Treat., 128, 298-305.

26. Kv N.S. 2021. Removal of Dyes From Industrial Effluents Using Bioremediation Technique. In: Aravind J., Kamaraj M., Prashanthi Devi M., Rajakumar S. (eds) Strategies and Tools for Pollutant Mitigation.

27. Kwon K., Kim H., Kim W. and Lee J. 2019. Efficient nitrogen removal of reject water generated from anaerobic digester treating sewage sludge and livestock manure by combining anammox and autotrophic Sulfur denitrification processes. Water, $11,204$.

28. Lebiocka M., Montusiewicz A. and Cydzik-Kwiatkowska A. 2018. Effect of bioaugmentation on biogas yields and kinetics in anaerobic digestion of sewage sludge. Int. J. Environ. Res. Public Health, $15,1717$.

29. Lens P.N., De Poorter M.P., CronenbergC.C. and Verstraete W.H. 1995. Sulfate reducing and methane producing bacteria in aerobic wastewater treatment systems. Water Res., 29, 871-880.
30. Liu Z., Xie H., Hu Z., Zhang J., Zhang, J., Sun H. and Lan, W. 2017. Role of Ammonia-Oxidizing Archaea in Ammonia Removal of Wetland Under Low-Temperature Condition. Water. Air. Soil Pollut., 228, 356.

31. Łagód G., Duda S.M., Majerek D., Szutt A. and Dołhańczuk-Śródka A. 2019. Application of electronic nose for evaluation of wastewater treatment process effects at full-scale WWTP. Processes, 7, 251.

32. Ma F., Guo J., Zhao L.J., Chang C.C., Cui D. 2009. Application of bioaugmentation to improve the activated sludge system into the contact oxidation system treating petrochemical wastewater. Bioresour. Technol., 100 (2), 597-602.

33. Majtacz J., Grubba D., Kowal P. and Czerwionka K. 2020. Possibilities of leachate co-treatment originating from biogas production in the deammonification process. J. Ecol. Eng., 21, 14-19.

34. Majtacz J., Kowal P., Lu X., Al-Hazmi H. and Makinia J. 2017. Adaptation of the activated sludge to the digestate liquors during the nitrification and denitrification processes. J. Ecol. Eng., 18, 104-109.

35. Makinia J., Wells S.A. and Zima P. 2005. Temperature Modeling in Activated Sludge Systems: A Case Study. Water Environ. Res., 77, 525-532.

36. Masłoń A., Czarnota J., Szaja A., Szulżyk-Cieplak J.. and Lagód G. 2020. The enhancement of energy efficiency in a wastewater treatment plant through sustainable biogas use: Case study from Poland. Energies, 13, 6056.

37. Mehrani M.J., Sobotka D., Kowal P., Ciesielski S. and Makinia J. 2020, The occurrence and role of Nitrospira in nitrogen removal systems. Bioresour., 303, 122936.

38. Meyer S.S. and Wilderer P.A. 2004. Reject water: Treating of process water in large wastewater treatment plants in Germany - A case study. J. Environ. Sci. Heal. - Part A Toxic/Hazardous Subst. Environ. Eng., 39, 1645-1654.

39. Michalska J., Piński A., Zur J. and Mrozik, A. 2020. Selecting bacteria candidates for the bioaugmentation of activated sludge to improve the aerobic treatment of landfill leachate. Water, 12, 140.

40. Montusiewicz, A. 2014. Co-digestion of sewage sludge and mature landfill leachate in pre-bioaugmented system. J. Ecol. Eng., 15, 98-104.

41. Morgan-Sagastume F. andAllen D.G. 2003. Effects of temperature transient conditions on aerobic biological treatment of wastewater. Water Res., 37, 3590-3601.

42. Mucha Z. and Mikosz J. 2021. Technological characteristics of reject waters from aerobic sludge stabilization in small and medium-sized wastewater treatment plants with biological nutrient removal. Int. J. Energy Environ. Eng., 12, 69-76.

43. Nguye, P.Y., Silva A.F., Reis A.C., Nunes O.C., Rodrigues A.M., Rodrigues J.E., Cardoso V.V., 
Benoliel M.J., Reis M.A.M., Oehmen A. and Carvalho G. 2019. Bioaugmentation of membrane bioreactor with Achromobacterdenitrificans strain PR1 for enhanced sulfamethoxazole removal in wastewater. Sci. Total Environ., 648, 44-55.

44. Noutsopoulos C., Mamais D., Statiris E., Lerias E., Malamis S. and Andreadakis A. 2018. Reject water characterization and treatment through short-cut nitrification/denitrification: assessing the effect of temperature and type of substrate. J. Chem. Technol. Biotechnol., 93, 3638-3647.

45. Nzila A., Razzak S.A. and Zhu, J. 2016. Bioaugmentation: An emerging strategy of industrial wastewater treatment for reuse and discharge. Int. J. Environ. Res. Public Health, 13, 846.

46. Plaza E., Trela J. and Hultman B. 2001. Impact of seeding with nitrifying bacteria on nitrification process efficiency. Water Sci. Technol., 43, 155-163.

47. Podstawczyk D., Witek-Krowiak A., DawiecLiśniewska A., Chrobot P. and Skrzypczak, D. 2017. Removal of ammonium and orthophosphates from reject water generated during dewatering of digested sewage sludge in municipal wastewater treatment plant using adsorption and membrane contactor system. J. Clean. Prod., 161, 277-287.

48. Regmi P., Miller M.W., Holgate B., Bunce R., Park H., Chandran K., Wett B., Murthy, S. and Bott C.B. 2014. Control of aeration, aerobic SRT and COD input for mainstream nitritation/denitritation. Water Res., 57, 162-171.

49. Rodziewicz J., Ostrowska K., Janczukowicz W. and Mielcarek A. 2019. Effectiveness of nitrification and denitrification processes in biofilters treating waste water from de-icing airport runways. Water, 11, 630.

50. Roots P., Sabba F., Rosenthal A.F.; Wang Y., Yuan Q., Rieger L., Yang F., Kozak J.A., Zhang H. and Wells G.F. 2020. Integrated low-energy and low carbon shortcut nitrogen removal with biological phosphorus removal for sustainable mainstream wastewater treatment. Environ. Sci.: Water Res. Technol. ,6, 566-580.

51. Roots P., Wang Y., Rosenthal A.F., Griffin J.S., Sabba F., Petrovich M., Yang F., Kozak J.A., Zhang H. and Wells G.F. 2019. ComammoxNitrospira are the dominant ammonia oxidizers in a mainstream low dissolved oxygen nitrification reactor. Water Res., 157, 396-405.

52. Shahzad M., Khan S.J. and Paul P. 2015. Influence of temperature on the performance of a full-scale activated sludge process operated at varying solids retention times whilst treating municipal sewage. Water, 7, 855-867.

53. Shourjeh M.S., Kowal P., Drewnowski J., Szeląg B., Szaja A. and Łagód G. 2020. Mutual Interaction between Temperature and DO Set Point on AOB and NOB Activity during Shortcut Nitrification in a Sequencing Batch Reactor in Terms of Energy Consumption Optimization. Energies, 13, 5808.
54. Shourjeh M.S., Kowal P., Lu X., Xie L. and Drewnowski J. 2021. Development of strategies for AOB and NOB competition supported by mathematical modeling in terms of successful deammonification implementation for energy-efficient WWTPs. Processes, 9, 562.

55. Sperczyńska E. 2016. Use of Zeolite for Removal of Ammonium Nitrogen from Reject Water. Eng. Prot. Environ., 19, 391-399.

56. Strous M., Van Gerven E., Zheng P., Kuenen J.G. and Jetten M.S.M. 1997. Ammonium removal from concentrated waste streams with the anaerobic ammonium oxidation (anammox) process in different reactor configurations. Water Res., 31, 1955-1962.

57. Suschka J. and Grübel K. 2014. Nitrogen in the process of waste activated sludge anaerobic digestion. Arch. Environ. Prot., 40, 123-136.

58. Szaja A. and Szulzyk-Cieplak J. 2020. Influence of bioaugmentation strategy of activated sludge on the co-treatment of reject water and municipal wastewater at a decreasing temperature. J. Ecol. Eng., 21, 97-106.

59. Szaja A., Łagód G., Jaromin-Gleń K. and Montusiewicz A. 2018. The effect of bioaugmentation with Archaea on the oxygen uptake rate in a sequencing batch reactor. Water, 10, 575 .

60. Szeląg B. and Barbusiński K.2020. Impact of the selected indicators of the wastewater quality and operating parameters of the biological reactor on the simulation of sludge sedimentation: Probabilistic approach. Desalin. Water Treat., 186, 144-154.

61. Tchobanoglous G., Burton F.L.; and StenselH.D. 2004. Wastewater Engineering: Treatment and Reuse. Metcalf \& Eddy, McGraw-Hill Education: New York, NY, USA.

62. van Loosdrecht M.C.M. and Salem S. 2006. Biological treatment of sludge digester liquids. Water Sci. Technol., 53, 11-20.

63. Wett B., Rostek R., Rauch W. and Ingerle K. 1998. $\mathrm{pH}$-controlled reject water treatment. Wat. Sci. Tech.,37, 165-172.

64. Yin Z., Bi X. and Xu C. 2018. Ammonia-oxidizing archaea (AOA) play with ammonia-oxidizing bacteria $(\mathrm{AOB})$ in nitrogen removal from wastewater. Archaea, 2018, 8429145.

65. You J., Das A., Dolan E.M. and Hu Z. 2009.Ammonia-oxidizing archaea involved in nitrogen removal. Water Res., 43, 1801-1809.

66. Young B., Delatolla R., Kennedy K., Laflamme E. andStintzi, A. 2017. Low temperature MBBR nitrification: Microbiome analysis. Water Res., 111, 224-233.

67. Zubrowska-Sudol M., Podedworna J., Sytek-Szmeichel K., Bisak A., Krawczyk P. and Garlicka A. 2018. The effects of mechanical sludge disintegration to enhance full-scale anaerobic digestion of municipal sludge. Therm. Sci. Eng. Prog., 5, 289-295. 